\title{
ANALIZA PRAKSE IZVJEŠTAVANJA O DRUŠTVENOJ ODGOVORNOSTI DRUŠTAVA ZA OSIGURANJE I REOSIGURANJE
}

\section{CORPORATE SOCIAL DISCLOSURE PRACTICE OF THE INSURANCE AND REINSURANCE COMPANIES}

\begin{abstract}
SAŽETAK: U današnjem kompleksnom i turbulentnom okruženju organizacije su suočene s visokim stupnjem neizvjesnosti i nepredvidivosti u poslovanju, a kontinuirano unaprjeđenje poslovanja predstavlja značajnu komponentu strateškog pristupa u ostvarenju konkurentske prednosti. U tom kontekstu javlja se koncept društveno odgovornog poslovanja (DOP) kao sve značajnijeg elementa postizanja konkurentske prednosti. Budući da je primjena DOP-a sve više prisutna u poslovanju organizacija, cilj ovoga rada je analizirati praksu izvještavanja o društvenoj odgovornosti, odnosno, da li, i u kolikoj mjeri, društva za osiguranje i reosiguranje u Republici Hrvatskoj, Republici Srbiji te Bosni i Hercegovini izvještavaju o aktivnostima DOP-a na svojim internetskim stranicama. Na temelju dobivenih rezultata može se utvrditi da ne postoji značajna razlika u praksi izvještavanja o aktivnostima DOP-a u promatranim državama mjerena Indeksom izvještavanja o društvenoj odgovornosti koji iznosi 10,45 (RH), 9,3 (RS) i 5,78 (BIH), međutim, još uvijek ima dosta prostora za poboljšanjem u izvještavanju o mjerama i aktivnostima u području društvene odgovornosti.
\end{abstract}

KLJUČNE RIJEČI: društveno odgovorno poslovanje, Indeks izvještavanja o društvenoj odgovornosti, društva za osiguranje i reosiguranje

ABSTRACT: In the currently complex and turbulent environment, companies are faced with a high degree of uncertainty in business and continuous business improvement is an integral part of the strategic approach towards the achievement of competitive advantage. In this context, the Corporate Social Responsibility (CSR) is emerging as an increasingly important feature in the achievement of a competitive advantage. Since the use of CSR is increasingly present in business operations, the objective of this paper is to analyse

Doc. dr. sc. Ivana Dropulić, Sveučilište u Splitu, Ekonomski fakultet, Katedra za računovodstvo i reviziju, e-mail: ivana.dropulic@efst.hr 
the corporate social disclosure practice. That is, whether, and to what extent, insurance and reinsurance companies in the Republic of Croatia, the Republic of Serbia and Bosnia and Herzegovina report on CSR activities on their websites. The CSR reporting is similar in the observed countries, as measured by the Corporate Social Disclosure Index, which reaches 10.45 (HR), 9.3 (RS) and 5.78 (BA), however, there is still room for improvement in CSR disclosure practice.

KEYWORDS: Corporate Social Responsibility, Corporate Social Disclosure Index, insurance and reinsurance companies

\section{UVOD}

Društveno odgovorno poslovanje (DOP) može se promatrati kao konstrukt koji opisuje odnos između organizacije i društva, a predstavlja praksu poslovanja kojom organizacije dobrovoljno nastoje uskladiti svoje poslovanje s potrebama društva. Tijekom godina sve više organizacija izvještava o svojim društvenim i ekološkim ostvarenjima, a primjena DOP-a, kao sve značajnijeg elementa postizanja konkurentske prednosti i strategije poslovanja, postaje sastavni dio poslovnih procesa. Budući da se ipak radi o relativno novom konceptu, praksa društvene odgovornosti vrlo je raznolika te uvelike ovisi o kontekstu u kojem se odvija (Vrdoljak Raguž \& Hazdovac, 2014). Također, može se uočiti da sve veći broj organizacija primjenjuje i izvještava o aktivnostima DOP-a, što zbog pritiska javnosti, što zbog veće osviještenosti u poslovanju i obavljanju gospodarske djelatnosti (Hooghiemstra, 2000). Također, i Europska unija (EU) je prepoznala potrebu uspostave visoke i usporedive razine razmjene informacija vezanih uz okoliš, socijalno-kadrovska pitanja, ljudska prava, borbu protiv korupcije i podmićivanja te je stoga Europski parlament donio Direktivu 2014/95/EU koja je obvezala određenu kategoriju gospodarskih subjekata na izradu nefinancijskog izvješća.

Kao i u drugim djelatnostima tako i u djelatnosti osiguranja je prisutna primjena DOP-a, a izvještavanje o poduzetim aktivnostima društva je najčešće prezentirano na internetskim stranicama samih društava. Budući da se primjena DOP-a sve više popularizira, cilj ovoga rada je istražiti kako je djelatnost osiguranja prihvatila ovakav način poslovanja te da li o poduzetim aktivnostima izvještava na svojim internetskim stranicama. Odnosno, ovim radom želi se analizirati praksa izvještavanja o društvenoj odgovornosti društva za osiguravanje i reosiguranje u Republici Hrvatskoj (RH), Republici Srbiji (RS) te Bosni i Hercegovini (BIH), te utvrditi postoji li značajna razlika u praksi izvještavanja među promatranim državama mjerena Indeksom izvještavanja o društvenoj odgovornosti. Na razini RH, kao članice Europske unije, može se uočiti pozitivan trend u izvještavanju o aktivnostima DOP-a na internetskim stranicama koje je vjerojatno jednim dijelom posljedica navedene Direktive koja je u sklopu Zakona o računovodstvu (ZOR, NN 47/20) primjenjuje od poslovne godine 2017. Budući da RS spada u države kandidatkinje, odnosno BIH u potencijalne kandidatkinje pristupanja EU, za očekivati je također prisutnu praksu u izvještavanju o aktivnostima DOP-a zbog obveze provođenja pravila i propisa EU u svim područjima.

Ovim istraživanjem doprinosi se boljem razumijevanju prakse izvještavanja o aktivnostima DOP-a, prije svega u djelatnosti osiguranja RH, RS i BIH za koju je izvještavanje ključno, jer je riječ o vjerodostojnosti, ugledu i konkurentskoj diferencijaciji. Doprinos 
ovoga istraživanja je, također, i u vidu usporedbe prakse izvještavanja o DOP-a promatranih država, kao i usporedbe vrijednosti indeksa izvještavanja o društvenoj odgovornosti RH nakon donošenja Direktive 2014/95/EU. Prema rezultatima provedenog istraživanja može se zaključiti kako je praksa izvještavanja o DOP-u ujednačena u djelatnosti osiguranja promatranih država, ali ipak nedovoljno zastupljena, te je za očekivati da će u budućnosti, što zbog pritiska javnosti, što zbog veće osviještenosti u poslovanju, ali i zakonskih propisa njegova uloga i primjena dobivati na sve većem značaju, a izvještavanje o poduzetim aktivnostima iz područja društvene odgovornosti postati sastavnim dijelom poslovne prakse. Od poduzetih aktivnosti DOP-a korist imaju i sama društva za osiguranje i reosiguranje u obliku izgradnje pozitivnog imidža, jačanja konkurentske prednosti, povećanja tržišnog udjela, poboljšanja odnosa sa dionicima i sl. (Trynchuk et al., 2019). Ostatak rada se sastoji od četiri dijela. U sljedećem dijelu se definira pojam DOP-a u teoriji i praksi te objašnjava uloga i značaj DOP-a, odnosno njegova primjena i zastupljenost u djelatnosti osiguranja. Treći dio prikazuje istraživačku hipotezu i metodologiju istraživanja dok su u četvrtom dijelu prezentirani rezultati istraživanja. Temeljni zaključci do kojih se došlo provođenjem istraživanja te sugestije i smjernice za daljnja istraživanje ove problematike prikazani su na kraju rada.

\section{DRUŠTVENO ODGOVORNO POSLOVANJE U TEORIJI I PRAKSI}

Budući da se je stajalište o DOP-u mijenjalo tijekom vremena, DOP se u teoriji i praksi definira na različite načine tako da se neke od definicija preklapaju dok se druge značajno razlikuju, a nerijetko su čak i kontradiktorne (Dropulić \& Čular, 2019). Društveno odgovorno poslovanje (engl. Corporate Social Responsibility [CSR]) predstavlja koncept koji je sve popularniji, a koji je privukao svjetsku pozornost i stekao novi odjek u globalnoj ekonomiji (Jamali \& Mirshak, 2007). Svjetski poslovni savjet za održivi razvoj (World Business Council for Sustainable Development [WBCSD], 2002, 229) definirao je društveno odgovorno poslovanje kao ,predanost poslovanja organizacije u obliku doprinosa održivom gospodarskom razvoju, radu sa zaposlenicima, njihovim obiteljima, lokalnoj zajednici i društvu u cjelini kako bi se poboljšala njihova kvaliteta života“. Prema Wolska $(2017,58)$ glavni cilj koncepta DOP-a je ,zaštita socijalnog i ekonomskog života od ekonomskog relativizma, jačanje osjećaja ljudskog dostojanstva, moralnih i etičkih načela, poštivanja zakona, svih oblika društvene integracije i uzajamnog povjerenja dionika vodeći brigu o općem dobru." DOP opisuje odnos između organizacije i društva, a budući da je postao sastavni dio poslovanja, aktivnosti DOP-a se koriste za stvaranje pozitivnog korporativnog imidža te razvijanja pozitivnog odnosa s potrošačima i drugim dionicima (Sen \& Bhattacharya, 2001; Yoon, Gürhan-Canli \& Schwarz, 2006). Također, prema Kavitha i Anuradha (2016), DOP predstavlja predanost organizacije u osiguranju resursa i podrške aktivnostima usmjerenim na jačanje gospodarskog i društvenog razvoja. Prema tome, dobri poslovni rezultati više nisu jedino mjerilo uspješnosti organizacije koja sada treba ujednačeno voditi računa o svom ekonomskom, društvenom i okolišnom utjecaju dok DOP predstavlja poslovni model i način upravljanja u kojem se profit ostvaruje na društveno odgovoran način (Indeks DOP-a HGK i HRPSOR).

Međutim, prema Friedmanu (1962) postoji samo jedna društvena odgovornost poslovanja, a to je korištenje resursa organizacije kako bi se povećala dobit za vlasnike organizacije. Slijedom toga, ako bi organizacije angažirale resurse za društvene potrebe, kao što su dona- 
cije u dobrotvorne svrhe, one bi bitno smanjile prinose dioničara i profitabilnost (Pinkston \& Carroll, 1996). Kritičari ovog stajališta smatraju da organizacije postoje kako bi služile široj zajednici, odnosno, organizacije trebaju pridonositi cjelokupnom društvu, a ne isključivo izravnim korisnicima poslovanja organizacije (Kok et al., 2001). S obzirom na navedene rasprave i podijeljene stavove o DOP-u ne postoji jedna egzaktna definicija DOP-a budući da su se stavovi i uvjerenja mijenjali kroz povijest istraživanja ove problematike (Snider, Hill \& Martin, 2003; Wolska, 2017). Može se zaključiti kako u vezi koncepta DOP-a postaje mnoge kontraverze, pa tako postoje zagovornici koncepta koji u njemu vide određene prednosti kao što su poticanje dionika na suradnju koja je stabilna i bez nepravilnosti i prijevara; poticanje kupaca na kupovinu proizvoda od društveno odgovornih organizacija; etičko, socijalno i ekološko ponašanje utječe na veću učinkovitost i poboljšanje organizacijske kulture, a kao rezultat aktivnosti DOP-a brend organizacije postaje prepoznatljiv i ugledniji. Međutim, postoje i protivnici koncepta DOP-a koji u njemu vide brojne nedostatke kao što su troškovi u vezi implementacije koncepta; veća prodajna cijena proizvoda zbog nastalih troškova koja će ograničiti konkurentnost organizacije te obveza organizacije da rješava društvena pitanje koja mogu dovesti do određenih dilema i neugodnosti (Wolska, 2017).

Postoje brojna istraživanja u zemlji i svijetu o konceptu DOP-a, njegovom značaju i ulozi u organizaciji kao i praksi izvještavanja o poduzetim aktivnostima DOP-a. Neka od istraživanja o praksi izvještavanja o aktivnostima DOP-a provedena u RH te zemljama iz okruženja u financijskoj djelatnosti su prikazana u nastavku. Kundid (2012) te Kundid i Rogošić (2012) analizirali su praksu e-izvještavanja banaka u RH o njihovom društveno odgovornom djelovanju dok je Rogošić (2014) analizirala praksu izvještavanja o aktivnostima DOP-a na internetskim stranicama banaka u BIH, RH i Crnoj Gori. Rogošić i Čaljkušić (2015) su također analizirali praksu izvještavanja o društvenoj odgovornosti banaka u RH i Sloveniji primjenjujući sadržajnu analizu odnosno, konstruirajući Indeks izvještavanja o društvenoj odgovornosti. Kundid Novokmet i Bilić (2016) istraživali su utjecaj financijske krize na povećanje izvještavanja o društvenoj odgovornosti banaka u RH te pripremljenost banaka za nove regulatorne zahtjeve što se tiče nefinancijskog izvještavanja prema Direktivi 2014/95/EU.

Prema rezultatima novoobjavljenih istraživanja (Ding et al., 2020) DOP doprinosi otpornosti organizacije na krizu, u ovom slučaju uzrokovanu virusom COVID-19, pa tako cijene dionica korporacija koje su prije krize provodile više društveno odgovornih aktivnosti bilježe manji pad kao posljedicu ove krize. Ovakvi rezultati su u skladu sa stajalištem da ulaganja u DOP osnažuju neformalne veze između organizacije i njenih zaposlenika, dobavljača, kupaca te ostalih dionika, omogućavajući organizaciji da učinkovitije i efikasnije surađuje sa svojim dionicima čime se povećava vjerojatnost opstanka i budućeg uspjeha organizacije. Postoje mnoge potencijalne koristi za društva za osiguranje i reosiguranje od primjene DOP-a poput dugoročne održivosti i profitabilnosti kroz oblikovanje i utjecaj na konkurentsko okruženja, ali i cjelokupnu zajednicu (Kavitha \& Anuradha, 2016), međutim, unatoč tome, malobrojne su studije o primjeni koncepta DOP-a u djelatnosti osiguranja. Olowokudejo, Aduloju i Oke (2011) utvrdili su da su društva za osiguranje uključena u sva područja DOP-a što se pozitivno manifestira na organizacijsku učinkovitost. Hsu (2012) je istražio utjecaj informativnih reklama o aktivnostima DOP-a na korporativnu reputaciju i brend društava za životno osiguranje na Tajvanu te utvrdio da percepcija osiguranika o aktivnostima DOP-a društava za osiguranje ima pozitivne učinke na zadovoljstvo kupaca, korporativnu reputaciju i brend. Kavitha i Anuradha (2016) su analizirali važnost DOP-a u djelatnosti osiguranja te istražili različite aktivnosti DOP-a koja su poduzela vodeća dru- 
štva za osiguranje u Indiji, a koja su prepoznala važnost DOP-a. Ho, Huang i Ou (2018) te Lee (2019) su također istraživali ulogu i značaj DOP-a u djelatnosti osiguranja dok su Kaur i Kaur (2019) analizirali praksu izvještavanja o aktivnostima DOP-a na internetskim stranicama društava za osiguranje kao i utjecaj veličine, likvidnosti, starosti i profitabilnosti društva na stupanj izvještavanja o društvenoj odgovornosti. Dropulić i Čular (2019) su proveli istraživanje o utjecaju prakse izvještavanja o aktivnostima DOP-a na kvalitetu izvještavanja društava za osiguranje i reosiguranje u RH. Prema Trynchuk et al. (2019) društva za osiguranje i reosiguranje trebaju primjenjivati koncept društvene odgovornosti, odnosno djelovati odgovorno na način da ograničavaju vlastiti negativni utjecaj na grupe dionika te poticati zaposlenike, klijente i partnere na odgovornost kroz razne programe razvoja ljudskih resursa, etičke kodekse i sl.

\section{ISTRAŽIVAČKA HIPOTEZA I METODOLOGIJA}

Predmet ovoga istraživanja je izvještavanje o primjeni DOP-a na internetskim stranicama društava za osiguranje i reosiguranje koja djeluju na prostoru Republike Hrvatske (RH), Republike Srbije (RS) te Bosne i Hercegovine (BIH). U istraživanje su uključena društva koja se nalaze u registru Hrvatske agencije za nadzor financijskih usluga (RH), registru Narodne banke Srbije (RS) i registru Agencije za osiguranje u Bosni i Hercegovini (BIH). Prema prikupljenim podacima utvrđeno je da u RH ima 18, RS 20, a u BIH 27 društava za osiguranje i reosiguranje.

Kao uzorak ovoga istraživanja odabrana su društva za osiguranje i reosiguranje iz tri države, odnosno RH, RS i BIH budući da određeni broj istih društava (10 i više) djeluje na području dvije ili tri države. S obzirom na navedeno te činjenicu da društva za osiguranje i reosiguranje sve tri države djeluju u sličnom poslovnom i gospodarskom okruženju za očekivati je da će imati ujednačenu poslovnu praksu u vezi izvještavanja o aktivnostima DOP-a. Međutim, budući da je RH država članica EU može se očekivati viši stupanj u izvještavanju o aktivnostima DOP-a na internetskim stranicama kao posljedica, jednim dijelom, Direktive 2014/95/EU, koja je u sklopu ZOR (NN 47/20), obvezala određenu kategoriju gospodarskih subjekata na izradu nefinancijskog izvješća. Također, određeni institucionalni faktori kao što su bruto domaći proizvod (BDP) i inflacija kao makroekonomski pokazatelji te računovodstveni standardi, etično ponašanje i transparentnost vlade mogu utjecati na različitu praksu izvještavanja o aktivnostima DOP-a promatranih država (Rogošić, 2014). S obzirom na prethodno navedeno može se pretpostaviti da:

\section{H1: Ne postoji značajna razlika u praksi izvještavanja o društvenoj odgovornosti društava za osiguranje i reosiguranje u RH, RS i BIH.}

Zbog složenosti koncepta DOP-a te nedostatka konsenzusa među istraživačima, u literaturi postoje različiti pristupi u mjerenju istoga kao što su razni indeksi specijaliziranih agencija za ocjenjivanje (npr. MSC KLD 400 indeks), sadržajna analiza, anketni upitnik i jednodimenzionalne mjere (Galant \& Cadez, 2017). U ovom istraživanju, kako bi se utvrdila razina izvještavanja o aktivnostima DOP-a, koristit će se sadržaja analiza (Karagiorgos, 2010; Khan, 2010; Kundid, 2012; Rogošić \& Kundid, 2012; Rogošić \& Čaljkušić, 2015; Chen, Feldmann \& Tang, 2015; Kaur \& Kaur, 2019; Dropulić \& Čular, 2019), odnosno, 
nakon definiranja aktivnosti unutar područja DOP-a koje su predmet istraživanja, relativno jednostavnim načinom kodiranja dobit će se integrirani rezultat.

Prema Rogošić i Čaljkušić (2015) aspekti u pogledu područja DOP-a su: pitanja ljudskih resursa, uključenost u zajednicu, dobročinstva, odnosi s klijentima, proizvodi i aktivnosti zaštite okoliša. Rogošić i Kundid (2012) su konstruirale Indeks izvještavanja o društvenoj odgovornosti banaka (engl. Bank Social Disclosure Indeks - BSDI) koji predstavlja svojevrsnu razvojnu putanju ocjene dobrovoljnog izvještavanja u tom segmentu, temeljenu na prethodnim istraživanjima, čiji je metodološki okvir korišten u ovome istraživanju, ali je prilagođen za djelatnost osiguranja u vidu određenih aktivnosti unutar područja DOP-a. Također, brojna druga istraživanja koristila su sadržajnu analizu, odnosno, konstruirala odgovarajuće indekse izvještavanja o društvenoj odgovornosti s obzirom na dostupne podatke na internetskim stranicama ili nefinancijskim i poslovnim izvješćima (Kaur \& Kaur, 2019; Dropulić \& Čular, 2019). Tablica 1 prikazuje Indeks izvještavanja o društvenoj odgovornosti koji se sastoji od šest područja DOP-a i to: ljudski resursi, uključenost u zajednicu i dobročinstvo, poslovna strategija i tržišni odnosi, odnosi s klijentima, proizvodi/usluge i zašita okoliša. Unutar svakog područja DOP-a nalaze se aktivnosti djelovanja kojih ukupno ima 24

Tablica 1: Indeks izvještavanja o društvenoj odgovornosti

\begin{tabular}{|c|c|}
\hline Područja DOP-a & Aktivnosti unutar područja DOP-a \\
\hline Ljudski resursi & $\begin{array}{l}\text { 1) Edukacija } \\
\text { 2) Poštivanje osnovnih ljudskih i radničkih prava } \\
\text { 3) Sigurnost na radu } \\
\text { 4) Zapošljavanje } \\
\text { 5) Ispitivanje i maksimalizacija zadovoljstva } \\
\text { 6) Jednakost među spolovima }\end{array}$ \\
\hline $\begin{array}{l}\text { Uključenost } \\
\text { u zajednicu i } \\
\text { dobročinstvo }\end{array}$ & $\begin{array}{l}\text { 7) Donacije za zdravstvo } \\
\text { 8) Donacije za znanost i obrazovanje } \\
\text { 9) Donacije i sponzorstva umjetnosti i kulture } \\
\text { 10) Donacije i sponzorstva sporta } \\
\text { 11) Donacije u humanitarne svrhe i organizacija humanitarnih programa } \\
\text { 12) Donacije humanitarnim organizacijama }\end{array}$ \\
\hline $\begin{array}{l}\text { Poslovna } \\
\text { strategija i tržišni } \\
\text { odnosi }\end{array}$ & $\begin{array}{l}\text { Antikorupcijski program } \\
\text { Etički kodeks } \\
\text { Zaštita osobnih podataka potrošača } \\
\text { Politika odnosa prema konkurenciji }\end{array}$ \\
\hline $\begin{array}{l}\text { Odnosi s } \\
\text { klijentima }\end{array}$ & $\begin{array}{l}\text { Nagrade } \\
\text { Posebne usluge }\end{array}$ \\
\hline Proizvodi/usluge & $\begin{array}{l}\text { Nagrade za proizvode/usluge } \\
\text { Razvoj proizvoda/usluga }\end{array}$ \\
\hline Zaštita okoliša & $\begin{array}{l}\text { Donacije za ekološke projekte } \\
\text { Interna politika zaštite okoliša } \\
\text { Eksterna politika zaštite okoliša } \\
\text { Posebni proizvodi za ekološke projekte } \\
\end{array}$ \\
\hline
\end{tabular}

Izvor: Dropulić, I. \& Čular, M. (2019). The effect of corporate social disclosure practice on reporting quality: evidence from the insurance sector in Croatia. Management: Journal of Contemporary Management Issues, 24(2), 23-38. 
Istraživanjem i proučavanjem internetskih stranica društava za osiguranje i reosiguranje, u periodu od lipnja do rujna 2019. godine, dodijeljena je ocjena svakom pojedinom društvu vrednovanjem aktivnosti unutar područja DOP-a ocjenom 1 ili $0(1$ - ako društvo izvještava, odnosno 0 - ako društvo ne izvještava o navedenoj aktivnosti). Visina konačno ostvarene ocjene ukazuje na informaciju koliko društava za osiguranje i reosiguranje promatranih država izvještavaju o aktivnostima DOP-a, odnosno koliko je razvijena praksa izvještavanja o DOP-u u djelatnosti osiguranja pojedine države.

\section{REZULTATI ISTRAŽIVANJA}

$\mathrm{Na}$ temelju dobivenih rezultata provedenog istraživanja može se analizirati praksa izvještavanja o društvenoj odgovornosti društava za osiguranje i reosiguranje promatranih država. Grafikon 1 prikazuje koliko društava za osiguranje i reosiguranje svake države izvještava o pojedinom području DOP-a, odnosno, o kojem se području najviše izvještava u pojedinoj državi.

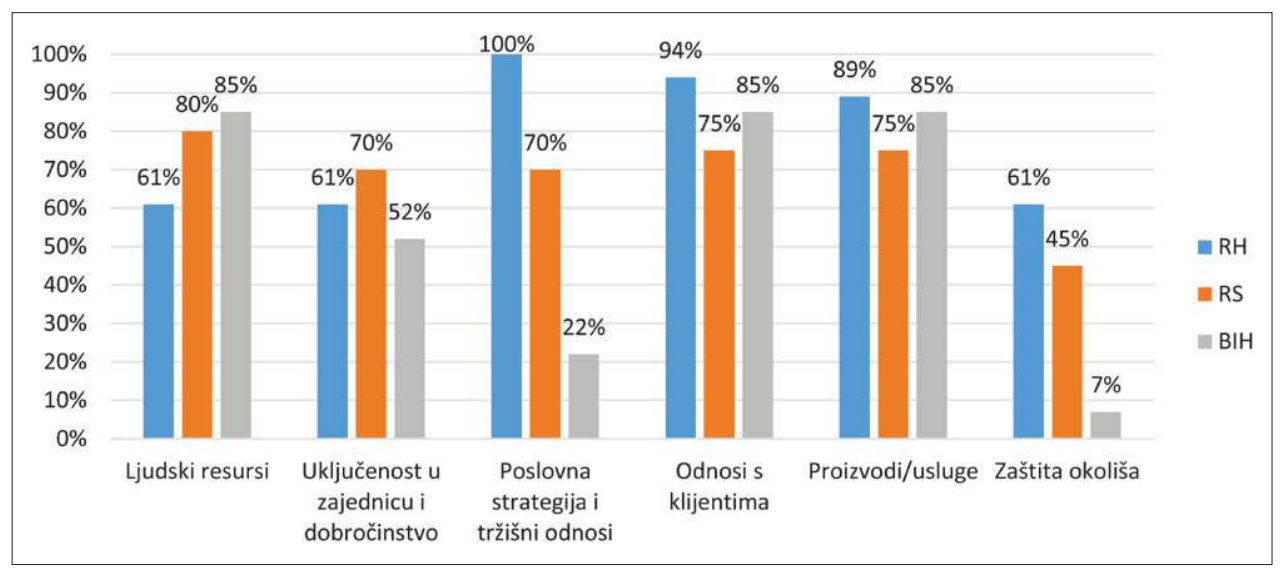

Grafikon 1: Društava za osiguranje i reosiguranje u RH, RS i BIH koja izvještavaju o pojedinom području DOP-a

Izvor: prikaz autora

Prema dobivenim rezultatima sva društva u RH izvještavaju o području poslovna strategija i tržišni odnosi, dok najmanje izvještavaju o području ljudski resursi (61\%), uključenost u zajednicu i dobročinstvo (61\%) te zaštita okoliša (61\%). Može se zaključiti kako društva u RH imaju visok stupanj izvještavanja po područjima DOP-a budući da o svakom području izvještava najmanje 11 (61\%) društava. Što se tiče društava u RS, 80\% društava izvještava o području ljudski resursi koje ujedno i predstavlja područje o kojem se najviše izvještava na internetskim stranicama, dok samo $45 \%$ društava izvještava o području zaštita okoliša. Ostala područja DOP-a su podjednako zastupljena u intervalu od 70\% do $75 \%$. U usporedbi sa društvima iz RH može se zaključiti da društva u RS više izvještavaju o samo dva područja DOP-a i to ljudski resursi (80\% u odnosu na 61\%) te uključenost u za- 
jednicu i dobročinstvo (70\% u odnosu na 61\%) dok je u ostala četiri područja izvještavanje društava u RH više u odnosu na RS. Kod društava u BIH, izvještavale o području ljudski resursi $(85 \%)$, odnosni s klijentima $(85 \%)$ i proizvodi/usluge $(85 \%)$ predstavljaju područja o kojima se najviše izvještava, dok je opet područje zaštita okoliša (7\%) najmanje zastupljeno. U usporedbi sa društvima iz RH i RS može se zaključiti da društva u BIH više izvještavaju o samo jednom području i to ljudski resursi (85\% u odnosu na $61 \%$ RH i $80 \%$ RS), a manje u tri područja i to uključenost u zajednicu i dobročinstvo (52\% u odnosu na $61 \%$ RH i $70 \%$ RS), poslovna strategija i tržišni odnosi (22\% u odnosu na $100 \%$ RH i $70 \%$ RS) te zaštita okoliša (7\% u odnosu na $61 \%$ RH i $45 \%$ RS).

Grafikon 2 prikazuje o koliko područja DOP-a pojedino društvo za osiguranje i reosiguranje u RH izvještava.

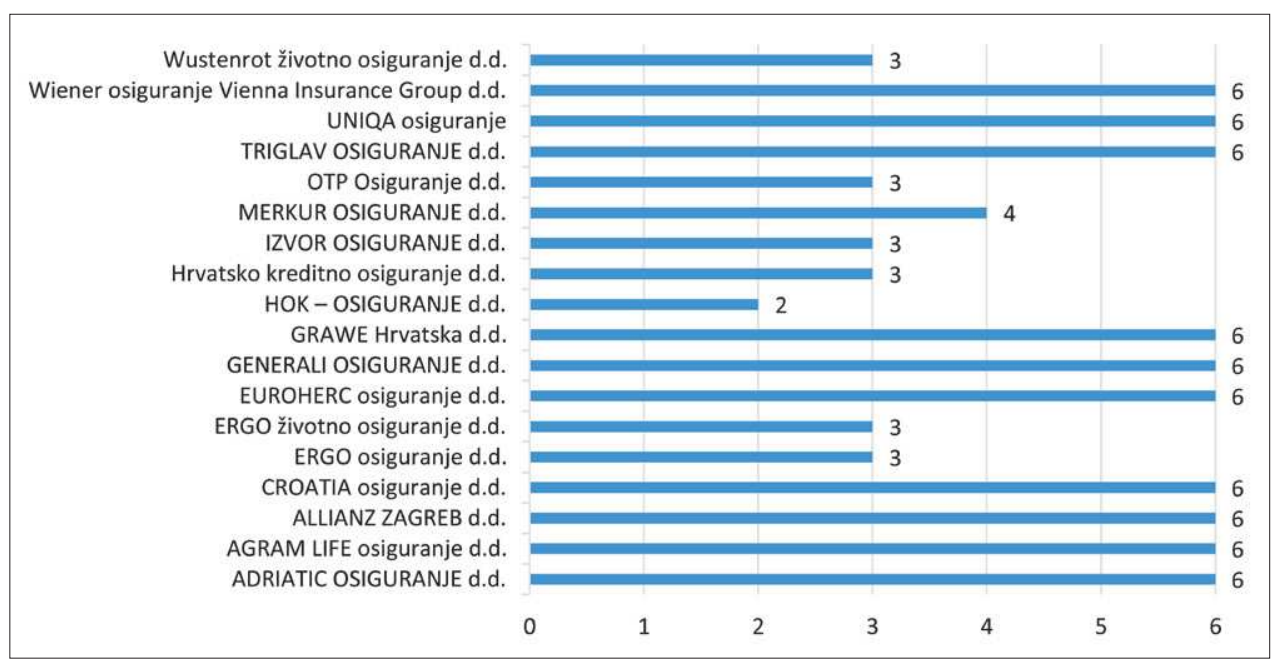

Grafikon 2: Broj područja DOP-a o kojima društva u RH izvještavaju

Izvor: prikaz autora

Na grafikonu 2 može se vidjeti da čak deset od osamnaest društava (56\%) u RH izvještava o svim područjima DOP-a, dok jedno društvo $(6 \%)$ izvještava o samo dva područja DOP-a na svojim internetskim stranicama. Također, može se zaključiti da nema nijedno društvo za osiguranje i reosiguranje koje ne izvještava o barem jednom području DOP-a na svojim internetskim stranicama.

Grafikon 3 prikazuje o koliko područja DOP-a pojedino društvo za osiguranje i reosiguranje u RS izvještava. 


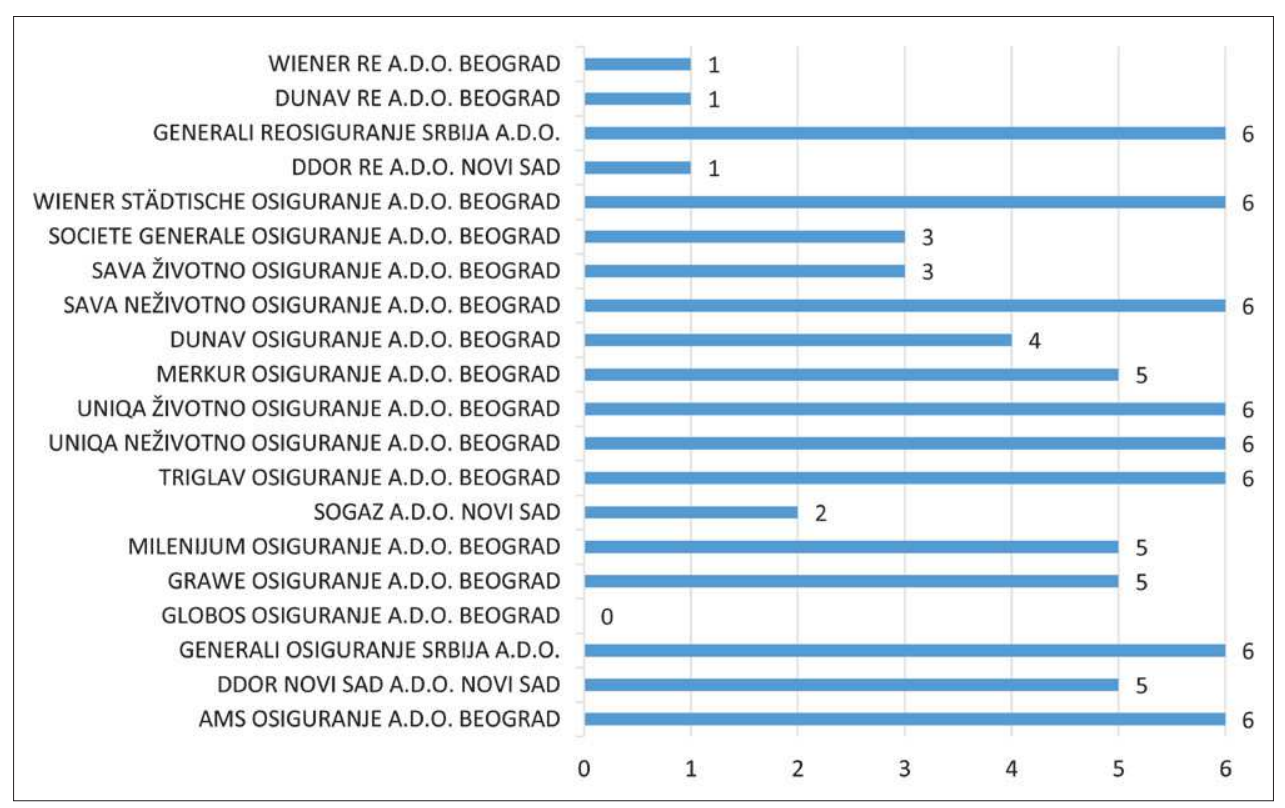

Grafikon 3: Broj područja DOP-a o kojima društva u RS izvještavaju

Izvor: prikaz autora

Za razliku od RH, u djelatnosti osiguranja RS postoji jedno društvo (5\%) koje uopće ne izvještava o primjeni DOP-a, odnosno o nijednoj aktivnosti iz šest područja DOP-a. Također, samo osam društava (40\%) izvještava o svim područjima DOP-a, dok tri društva (15\%) izvještavaju o samo jednom području DOP-a na svojim internetskim stranicama.

Grafikon 4 prikazuje o koliko područja DOP-a pojedino društvo za osiguranje i reosiguranje u BIH izvještava. Na grafikonu 4 se može vidjeti da samo jedno društvo (4\%) izvještava o apsolutno svim područjima DOP-a, dok jedno društvo (4\%) izvještava o samo jednom području DOP-a na svojim internetskim stranicama. Najveći broj društava (44\%) izvještava o tri područja DOP-a. Također, kao i kod društava u RH, nema nijedno društvo za osiguranje i reosiguranje koje uopće ne izvještava o primjeni DOP-a, odnosno, o barem jednom području DOP-a. 


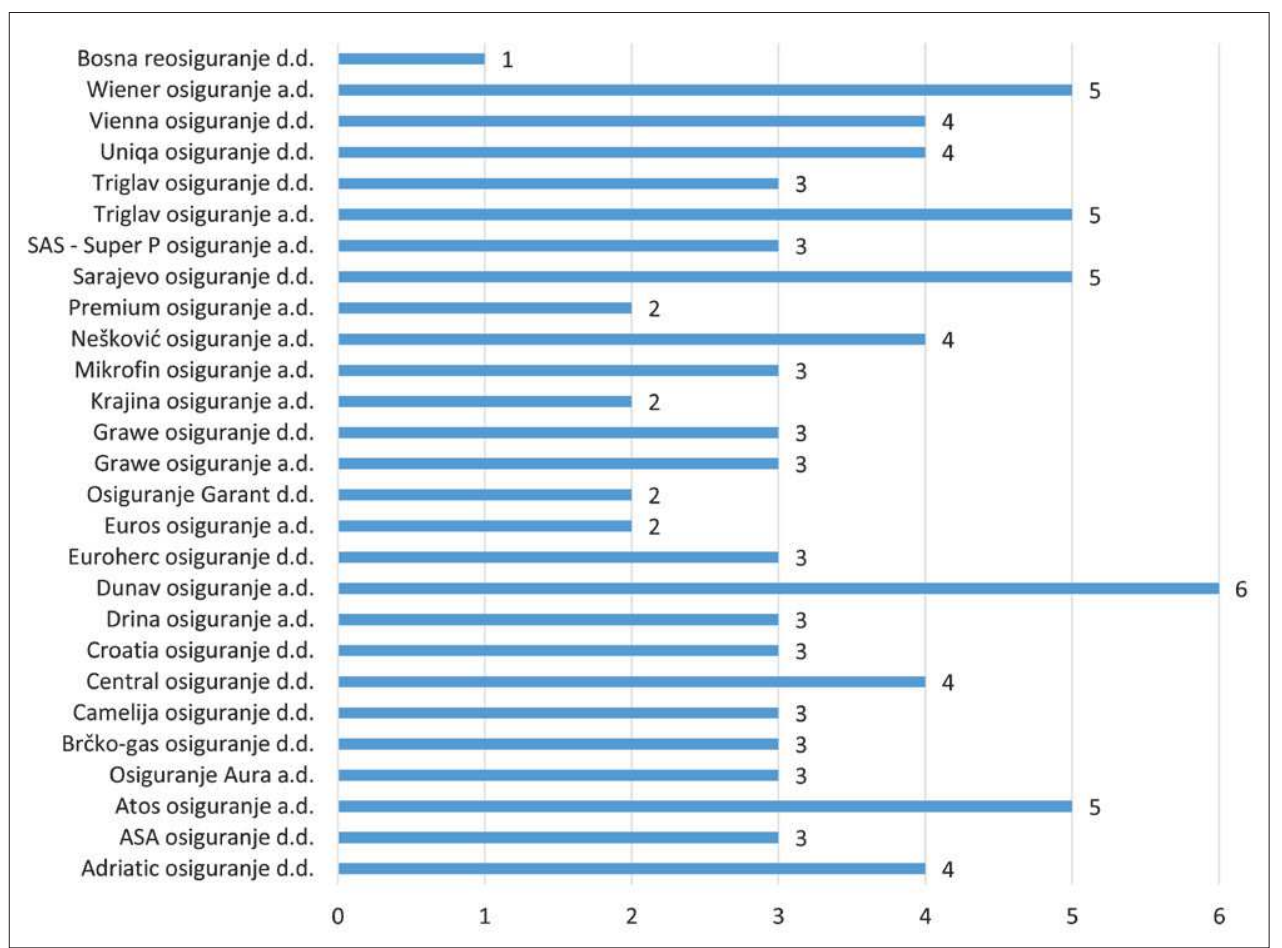

Grafikon 4: Broj područja DOP-a o kojima društva u BIH izvještavaju

Izvor: prikaz autora

Tablica 2 daje pregled ostvarenih bodova svih društava za osiguranje i reosiguranje u RH prema Indeksu izvještavanja o društvenoj odgovornosti (prosječan broj bodova 10,45 što predstavlja 43,52\%). 
Tablica 2: Indeks izvještavanja o društvenoj odgovornosti društava u RH

\begin{tabular}{|l|l|c|}
\hline Rb. & Društva za osiguranje i reosiguranje u RH & Broj bodova \\
\hline 1 & ADRIATIC OSIGURANJE d.d. & 18 \\
\hline 2 & AGRAM LIFE osiguranje d.d. & 12 \\
\hline 3 & ALLIANZ ZAGREB d.d. & 14 \\
\hline 4 & CROATIA osiguranje d.d. & 22 \\
\hline 5 & ERGO osiguranje d.d. & 3 \\
\hline 6 & ERGO životno osiguranje d.d. & 3 \\
\hline 7 & EUROHERC osiguranje d.d. & 15 \\
\hline 8 & GENERALI OSIGURANJE d.d. & 16 \\
\hline 9 & GRAWE Hrvatska d.d. & 13 \\
\hline 10 & HOK - OSIGURANJE d.d. & 2 \\
\hline 11 & Hrvatsko kreditno osiguranje d.d. & 3 \\
\hline 12 & IZVOR OSIGURANJE d.d. & 3 \\
\hline 13 & MERKUR OSIGURANJE d.d. & 4 \\
\hline 14 & OTP Osiguranje d.d. & 3 \\
\hline 15 & TRIGLAV OSIGURANJE d.d. & 14 \\
\hline 16 & UNIQA osiguranje & 20 \\
\hline 17 & Wiener osiguranje Vienna Insurance Group d.d. & 20 \\
\hline 18 & Wustenrot životno osiguranje d.d. & 3 \\
\hline Ukupan broj bodova & 188,45 \\
\hline Prosječan broj bodova & \\
\hline & & \\
\hline
\end{tabular}

Izvor: prikaz autora

Prema dobivenim rezultatima može se zaključiti da je praksa izvještavanja o društvenoj odgovornosti razvijena u djelatnosti osiguranja $\mathrm{RH}$, ali je prosjek ipak nizak s obzirom da je maksimalan broj bodova 24. Manji broj društava (8 ili 44\%) značajno odskače od prosjeka te ima manji broj bodova dok je veći broj društava (10 ili 56\%) s brojem bodova bližim prosjeku ili većim od prosjeka pa se može zaključiti da je veći broj onih društava koji izvještavaju o iznad prosječnom broju aktivnosti poduzetih iz područja društvene odgovornosti.

Tablica 3 daje pregled bodova svih društava za osiguranje i reosiguranje u RS prema Indeksu izvještavanja o društvenoj odgovornosti (prosječan broj bodova 9,3 ili 38,75\%). 
Tablica 3: Indeks izvještavanja o društvenoj odgovornosti društava u RS

\begin{tabular}{|c|c|c|}
\hline Rb. & Društva za osiguranje i reosiguranje u RS & Broj bodova \\
\hline 1 & AMS OSIGURANJE A.D.O. BEOGRAD & 12 \\
\hline 2 & DDOR NOVI SAD A.D.O. NOVI SAD & 13 \\
\hline 3 & GENERALI OSIGURANJE SRBIJA A.D.O. & 17 \\
\hline 4 & GLOBOS OSIGURANJE A.D.O. BEOGRAD & 0 \\
\hline 5 & GRAWE OSIGURANJE A.D.O. BEOGRAD & 11 \\
\hline 6 & MILENIJUM OSIGURANJE A.D.O. BEOGRAD & 9 \\
\hline 7 & SOGAZ A.D.O. NOVI SAD & 2 \\
\hline 8 & TRIGLAV OSIGURANJE A.D.O. BEOGRAD & 11 \\
\hline 9 & UNIQA NEŽIVOTNO OSIGURANJE A.D.O. BEOGRAD & 18 \\
\hline 10 & UNIQA ŽIVOTNO OSIGURANJE A.D.O. BEOGRAD & 18 \\
\hline 11 & MERKUR OSIGURANJE A.D.O. BEOGRAD & 10 \\
\hline 12 & DUNAV OSIGURANJE A.D.O. BEOGRAD & 11 \\
\hline 13 & SAVA NEŽIVOTNO OSIGURANJE A.D.O. BEOGRAD & 15 \\
\hline 14 & SAVA ŽIVOTNO OSIGURANJE A.D.O. BEOGRAD & 3 \\
\hline 15 & SOCIETE GENERALE OSIGURANJE A.D.O. BEOGRAD & 4 \\
\hline 16 & $\begin{array}{l}\text { WIENER STÄDTISCHE OSIGURANJE A.D.O. } \\
\text { BEOGRAD }\end{array}$ & 11 \\
\hline 17 & DDOR RE A.D.O. NOVI SAD & 1 \\
\hline 18 & GENERALI REOSIGURANJE SRBIJA A.D.O. & 17 \\
\hline 19 & DUNAV RE A.D.O. BEOGRAD & 1 \\
\hline 20 & WIENER RE A.D.O. BEOGRAD & 2 \\
\hline \multicolumn{2}{|c|}{ Ukupan broj bodova } & 186 \\
\hline \multicolumn{2}{|c|}{ Prosječan broj bodova } & 9,3 \\
\hline
\end{tabular}

Izvor: prikaz autora

Iako ostvareni prosječni broj bodova ukazuje kako je praksa izvještavanja o društvenoj odgovornosti prisutna u djelatnosti osiguranja RS, prosječna ostvarena ocjena je niska. Postoji 7 društava (35\%) koji imaju značajno manji broj bodova od prosjeka uključujući i jedno društvo koje je ostvarilo 0 bodova prema Indeksu izvještavanja o društvenoj odgovornosti. Ostala društva, odnosno njih 13 (65\%) ostvarilo je broj bodova bliži ili veći od prosjeka djelatnosti osiguranja RS. Ukoliko se usporede dobiveni rezultati s rezultatima djelatnosti osiguranja RH, može se uočiti da je izvještavanje o aktivnostima društvene odgovornosti podjednako zastupljeno u promatranim državama s blagom većom vrijednošću Indeksa izvještavanja o društvenoj odgovornosti u RH.

U tablici 4 prikazan je broj bodova društava za osiguranje i reosiguranje u BIH prema Indeksu izvještavanja o društvenoj odgovornosti (prosječan broj bodova 5,78 ili 24,07\%). 
Tablica 4: Indeks izvještavanja o društvenoj odgovornosti društava u BIH

\begin{tabular}{|c|c|c|}
\hline Rb. & Društva za osiguranje i reosiguranje u BIH & Broj bodova \\
\hline 1 & Adriatic osiguranje d.d. & 4 \\
\hline 2 & ASA osiguranje d.d. & 8 \\
\hline 3 & Atos osiguranje a.d. & 7 \\
\hline 4 & Osiguranje Aura a.d. & 5 \\
\hline 5 & Brčko-gas osiguranje d.d. & 4 \\
\hline 6 & Camelija osiguranje d.d. & 4 \\
\hline 7 & Central osiguranje d.d. & 4 \\
\hline 8 & Croatia osiguranje d.d. & 3 \\
\hline 9 & Drina osiguranje a.d. & 4 \\
\hline 10 & Dunav osiguranje a.d. & 9 \\
\hline 11 & Euroherc osiguranje d.d. & 7 \\
\hline 12 & Euros osiguranje a.d. & 2 \\
\hline 13 & Osiguranje Garant d.d. & 6 \\
\hline 14 & Grawe osiguranje a.d. & 3 \\
\hline 15 & Grawe osiguranje d.d. & 3 \\
\hline 16 & Krajina osiguranje a.d. & 4 \\
\hline 17 & Mikrofin osiguranje a.d. & 6 \\
\hline 18 & Nešković osiguranje a.d. & 7 \\
\hline 19 & Premium osiguranje a.d. & 6 \\
\hline 20 & Sarajevo osiguranje d.d. & 10 \\
\hline 21 & SAS - Super P osiguranje a.d. & 4 \\
\hline 22 & Triglav osiguranje a.d. & 6 \\
\hline 23 & Triglav osiguranje d.d. & 6 \\
\hline 24 & Uniqa osiguranje d.d. & 13 \\
\hline 25 & Vienna osiguranje d.d. & 10 \\
\hline 26 & Wiener osiguranje a.d. & 9 \\
\hline 27 & Bosna reosiguranje d.d. & 2 \\
\hline \multicolumn{2}{|c|}{ Ukupan broj bodova } & 156 \\
\hline \multicolumn{2}{|c|}{ Prosječan broj bodova } & 5,78 \\
\hline
\end{tabular}

Izvor: prikaz autora

Prema Indeksu izvještavanja o društvenoj odgovornosti ostvareni broj bodova je dosta nizak što ukazuje na činjenicu da djelatnost osiguranja BIH nema razvijenu praksu izvještavanja o aktivnostima DOP-a na svojim internetskim stranicama. Ukoliko se usporede dobiveni rezultati s rezultatima djelatnosti osiguranja RH i RS može se uočiti da je, prema Indeksu izvještavanja o društvenoj odgovornosti, zastupljenost izvještavanja o aktivnostima društvene odgovornosti u BIH niže u odnosu na druge dvije države (za 45\% u odnosu na RH i $38 \%$ u odnosu na RS). 
Razlozi ovakvih razlika u vrijednosti Indeksa izvještavanja o društvenoj odgovornosti promatranih država mogu biti različiti. Na primjer, sa stajališta institucionalne teorije, manja je vjerojatnost da će organizacije djelovati na društveno odgovoran način u situaciji kada posluju u relativno nezdravom ekonomskom okruženju (Campbell, 2007; Chih, Chih \& Chen, 2010, Rogošić, 2014). Također, određeni institucionalni faktori kao BDP i inflacija (World Development Indicators, 2018) te računovodstveni standardi i transparentnost (The Global Competitiveness Report, 2018) mogu utjecati na praksu izvještavanja o aktivnostima DOP-a promatranih država (Rogošić, 2014). Osim toga treba uzeti u obzir i različite kontingencijske faktore koji mogu utjecati na praksu izvještavanja o DOP-u, ali i financijske performanse samih društava.

Razlika u praksi izvještavanja o društveno odgovornosti društava za osiguranje i reosiguranje u RH, RS i BIH postoji, međutim, istu je potrebno statistički testirati kako bi se utvrdila njena značajnost. Budući da se istraživanje provodi na uzorku društava za osiguranje i reosiguranje u RH, RS i BIH, proveden je neparametrijski test, odnosno Kruskal-Wallis test koji se temelji na rangiranju (tablica 5).

Tablica 5: Kruskal-Wallis test

\begin{tabular}{|l|c|c|}
\hline \multicolumn{1}{|c|}{ Država } & $\begin{array}{c}\text { Broj društava za osiguranje } \\
\text { i reosiguranje }\end{array}$ & Prosječni rang \\
\hline RH & 18 & 37,89 \\
\hline RS & 20 & 35,58 \\
\hline BIH & 27 & 27,83 \\
\hline Ukupno & 65 & \multicolumn{2}{|c|}{ Indeks } \\
\hline & \multicolumn{2}{|c|}{3,619} \\
\hline Hi kvadrat & \multicolumn{2}{|c|}{0,164} \\
\hline DF & \multicolumn{2}{|c|}{0,164} \\
\hline P vrijednost & \multicolumn{2}{|c|}{} \\
\hline
\end{tabular}

Izvor: prikaz autora

S obzirom da je p-vrijednost 0,164 može se zaključiti kako ne postoji statistički značajna razlika u broju ostvarenih bodova društava za osiguranje i reosiguranje, prema Indeksu izvještavanja o društvenoj odgovornosti, po promatranim državama. Odnosno, može se prihvatiti istraživačka hipoteza da ne postoji značajna razlika u praksi izvještavanja o društvenoj odgovornosti društava za osiguranje i reosiguranje u RH, RS i BIH.

\section{ZAKLJUČAK}

Izvještavanje koje uz financijske informacije uključuje i nefinancijske informacije, odnosno informacije o aktivnostima iz područja DOP-a sve je više zastupljeno u suvremenom poslovanju i poslovnoj praksi. Rezultati istraživanja o izvještavanju o poduzetim aktivnostima iz područja DOP-a na internetskim stranicama društava za osiguranje i reosiguranje u RH, RS i BIH ukazuju kako djelatnost osiguranja promatranih država iz- 
vještava o aktivnostima DOP-a u određenom stupnju. Međutim, postoje razlike u praksi izvještavanja te obujmu informacija koje društva javno objavljuju na svojim internetskim stranicama. Određena društva objavljuju informacije o poduzetim aktivnostima iz područja DOP-a unutar posebnih odjeljaka na svojim internetskim stanicama dok određena društva imaju posebno nefinancijsko izvješće sa informacija o poduzetim aktivnostima iz područja DOP-a. Također, mali broj društava objavljenje informacije o poduzetim aktivnostima iz područja DOP-a potkrjepljuje primjerima iz prakse. Prema prikupljenim podacima može se zaključiti da društva za osiguranje i reosiguranje u RH, RS i BIH izvještavaju najviše o aktivnostima iz područja odnosi s klijentima (85\%), zatim proizvodi/usluge (83\%) te ljudski resursi (77\%). Područje DOP-a, iz kojeg se najmanje izvještava o poduzetim aktivnostima, jest zaštita okoliša (34\%). Nadalje, najveći broj društva u RH, RS i BIH izvještava o aktivnostima iz tri područja DOP-a (31\%) dok iz svih šest područja DOP-a izvještava $29 \%$ društava. Također, postoji jedno društvo iz RS koje ne izvještava o nijednoj aktivnosti iz bilo kojeg područja DOP-a što predstavlja $2 \%$ od ukupnog broja društava promatranih država. Budući da DOP predstavlja strateško sredstvo pozicioniranja, ono treba postati ključni element identiteta društava za osiguranje i reosiguranje.

Prema Indeksu izvještavanja o društvenoj odgovornosti prosječan broj bodova djelatnosti osiguranja RH iznosi 10,45 bodova ili 43,52\% što ukazuje kako je praksa izvještavanja o aktivnostima DOP-a prisutna u djelatnosti osiguranja. Međutim, ima dosta prostora za poboljšanje budući da društva za osiguranje i reosiguranje u RH spadaju u subjekte od javnog interesa prema ZOR (NN 47/20), potrebno je da u svoje izvješće poslovodstva uključe i nefinancijsko izvješće koje sadržava informacije o učincima njegovih aktivnosti koji se odnose na okolišna, socijalna i kadrovska pitanja, poštivanje ljudskih prava, borbu protiv korupcije te pitanja u vezi s podmićivanjem. Prosječan broj bodova djelatnosti RS, prema Indeksu izvještavanja o društvenoj odgovornosti, iznosi 9,3 boda ili 38,75\% što ukazuje kako je praksa izvještavanja o aktivnostima DOP-a također prisutna u djelatnosti osiguranja i prihvaćeno od strane društava, međutim kao i kod RH potrebno je dodatno poboljšanje u izvještavanju o dodatnim aktivnostima u području društvene odgovornosti. Od promatrane tri države djelatnost osiguranja u BIH ima najniži prosječan broj bodova koji iznosi samo 5,78 bodova, odnosno $24,07 \%$. Kako se može vidjeti iz rezultata istraživanja, iako postoji razlika u praksi izvještavanja o društvenoj odgovornosti društava za osiguranje i reosiguranje u RH, RS i BIH, ona nije statistički značajna.

Glavni nedostatak ovoga istraživanja je u vidu mjerenja DOP-a, odnosno izvještavanja o poduzetim aktivnostima istoga budući da se je koristila sadržajna analiza pri utvrđivanju Indeksa izvještavanja o društvenoj odgovornosti. Nedostatak ovoga pristupa su subjektivnost u svim fazama procesa istraživanja od odabira aktivnosti DOP-a, prikupljanja, interpretacije i kodiranja podataka. Također, izvještavanje o aktivnostima DOP-u uglavnom je dobrovoljno, a informacije koje organizacije objavljuju o aktivnostima DOP-a treba uzimati sa zadrškom budući da organizacije mogu pristrano izvještavati u cilju stvaranja boljeg imidža. Buduća istraživanja o praksi izvještavanja o aktivnostima DOP-a društava za osiguranje i reosiguranje trebala bi primijeniti i druge pristupe u mjerenju istoga kao što su neki od indeksa specijaliziranih agencija za ocjenjivanje kako bi se smanjila subjektivnosti istraživača. Također, zanimljivo bi bilo povezati praksu izvještavanja o aktivnostima DOP-a sa financijskim performansama (računovodstveno ili tržišno baziranim indikatorima) budući da usprkos brojnim istraživanjima o vezi između DOP-a i financijskih performansi organizacije u literaturi ne postoji usuglašen zaključak navedenog odnosa (vidjeti Yang, 
Lin \& Chang, 2010; Chen, Feldmann \& Tang, 2015). Osim toga, s obzirom na promjene u zakonskoj regulativi nefinancijskog izvještavanja, zanimljivo bi bilo pratiti daljnji trend izvještavanja o aktivnostima DOP-a u ovoj djelatnosti, kako RH, tako i država iz okruženja.

\section{LITERATURA}

1. Agencija za osiguranje u BiH: http://www.azobih.gov.ba/cms/index.php?option=com_content\&task=view\&id=91\&Itemid=70 (pristup: 30.05 .2019 .)

2. Campbell, J.L. (2007). Why Would Corporations Behave in Socially Responsible Ways? An Institutional Theory of Corporate Social Responsibility. Academy of Management Review, 32(3), 946-967.

3. Chen, 1., Feldmann, A. \& Tang, O. (2015). The relationship between disclosure of corporate social performance and financial performance: Evidence from GRI reports in manufacturing industry. International Journal of Production Economics, 170, 445-456.

4. Chih, H-L., Chih, H-H. \& Chen, T-Y. (2010). On the Determinants of Corporate Social Responsibility: International Evidence on the Financial Industry. Journal of Business Ethics, 93, 115-135.

5. Ding, W., Levine, R., Lin, C. \& Xie, W. (2020). Corporate Immunity to the COVID-19 Pandemic. Available at SSRN: https://ssrn.com/abstract=3578585 or http:// dx.doi.org/10.2139/ssrn.3578585 (pristup: 12.05.2020.)

6. Direktiva2014/95/EU,SlužbenilistEuropskeunije,L330,15 studenoga2014.https://eurlex.europa.eu/legal-content/HR/TXT/HTML/?uri=CELEX:32014L0095\&from=EN (pristup: 13.10.2019.)

7. Dropulić, I. \& Čular, M. (2019). The effect of corporate social disclosure practice on reporting quality: evidence from the insurance sector in Croatia. Management: Journal of Contemporary Management Issues, 24(2), 23-38.

8. Friedman, M. (1962). Capitalism and Freedom. Chicago: University of Chicago Press.

9. Galant, A. \& Cadez. S. (2017). Corporate social responsibility and financial performance relationship: a review of measurement approaches. Economic Research-Ekonomska Istraživanja, 30(1), 676-693.

10. Ho, C-C, Huang, C. \& Ou, C-Y. (2018). Analysis of the Factors influencing Sustainable Development in the Insurance Industry: Insurance Industry Sustainable Development. Corporate Social Responsibility and Environmental Management, 25(4), 391-410.

11. Hooghiemstra, R. (2000). Corporate Communication and Impression Management-New Perspectives Why Companies Engage in Corporate Social Reporting. Journal of Business Ethics, 27(1), 55-68.

12. Hrvatska agencija za nadzor financijskih usluga (HANFA): https://www.hanfa.hr/ trziste-osiguranja/registri/drustva-za-osiguranje-i-drustva-za-reosiguranje/ (pristup: 30.05.2019.)

13. Hsu, K. T. (2012). The Advertising Effects of Corporate Social Responsibility on Corporate Reputation and Brand Equity: Evidence from the Life Insurance Industry in Taiwan. Journal of Business Ethics, 109(2), 189-201. 
14. Indeks DOP-a HGK i HRPSOR: https://dop.hgk.hr/ (pristup: 12.05.2020.)

15. Jamali, D. \& Mirshak, R. (2007). Corporate Social Responsibility (CSR): Theory and Practice in a Developing Country Context. Journal of Business Ethics, 72, 243-262.

16. Karagiorgos, T. (2010). Corporate social responsibility and financial performance: An empirical analysis on Greek companies. European Research Studies, 13, 85-108.

17. Kaur, A. \& Kaur, R. (2019). Web Disclosure of Corporate Social Responsibility: A Study of Indian Insurance Companies. International Journal of Banking, Risk and Insurance, 7(1), 13-24.

18. Kavitha, N. V. \& Anuradha, T. (2016). Corporate Social Responsibility in Insurance Sector in India. International Journal of Innovative Research \& Development, 5(2), 137-143.

19. Khan, H. (2010). The Effect of Corporate Governance Elements on Corporate Social Responsibility (CSR) Reporting: Empirical Evidence from Private Commercial Banks of Bangladesh. International Journal of Law and Management, 52(2), 82-109.

20. Kok, P., Wiele, T., McKenna, R. \& Brown, A. (2001). A Corporate Social Responsibility Audit within a Quality Management Framework. Journal of Business Ethics, 31(4), 285-297.

21. Kundid Novokmet, A. \& Bilić, B. (2016). Društvena odgovornost banaka u vrijeme financijske krize: ususret direktivi Europske unije o nefinancijskom izvještavanju. Oeconomica Jadertina, 6(1), 54-69.

22. Kundid, A. \& Rogošić, A. (2012). E-transparency of Croatian Banks: Determinants and Disclosure Contents. Economic Research-Ekonomska Istraživanja, 25(1), 86-116.

23. Kundid, A. (2012). Društveno odgovorno poslovanje banaka u Republici Hrvatskoj. Ekonomska misao i praksa, (2), 497-528.

24. Lee, C.-Y. (2019) Does Corporate Social Responsibility Influence Customer Loyalty in the Taiwan Insurance Sector? The role of Corporate Image and Customer Satisfaction. Journal of Promotion Management, 25(1), 43-64.

25. Narodna banka Srbije: https://www.nbs.rs/internet/latinica/60/60_1/index.html (pristup: 30.05.2019.)

26. Olowokudejo, F., Aduloju, S. A. \& Oke, S. A. (2011). Corporate social responsibility and organizational effectiveness of insurance companies in Nigeria. The Journal of Risk Finance, 12(3), 156-167.

27. Pinkston, T. S. \& Carroll, A. B. (1996). A Retrospective Examination of CSR Orientations: Have They Changed? Journal of Business Ethics, 15(2), 199-206.

28. Rogošić, A. \& Čaljkušić, A. (2015). Disclosure of the Socially Responsible Activities of the Banks in Croatia and Slovenia. In D. Tipurić \& M. Daraboš (Eds.), 3rd International OFEL Conference on Governance, Management and Entrepreneurship (pp. 313-324). Zagreb, Croatia: CIRU - Governance Research and Development Centre.

29. Rogošić, A. \& Kundid, A. (2012). Izvještavanje o društvenoj odgovornosti banaka u Hrvatskoj. Praktični menadžment, 3(2), 15-20.

30. Rogošić, A. (2014). Corporate social responsibility reporting of the banks in Bosnia and Herzegovina, Croatia and Montenegro. Theoretical and Applied Economics, 21(9), 71-82. 
31. Sen, S. \& Bhattacharya, C. B. (2001). Does Doing Good Always Lead to Doing Better? Consumer Reactions to Corporate Social Responsibility. Journal of Marketing Research, 38(2), 225-243.

32. Snider, J., Hill, R. P. \& Martin, D. (2003). Corporate Social Responsibility in the 21st Century: A View from the World's Most Successful Firms. Journal of Business Ethics, 48(2), 175-187.

33. Trynchuk, V., Khovrak, I., Dankiewicz, R., Ostrowska-Dankiewicz, A. \& Chushak-Holoborodko, A. (2019). The role of universities in disseminating the social responsibility practices of insurance companies. Problems and Perspectives in Management, 17(2), 449-461.

34. Vrdoljak Raguž, I. \& Hazdovac, K. (2014). Društveno odgovorno poslovanje i hrvatska gospodarska praksa. Oeconomica Jadertina, 4(1), 40-58.

35. Wolska, G. (2017). Corporate social responsibility (CSR) in theory and in practice. Selected issues. DIEM, 3(1), 56-65.

36. World Bank (2018). World Development Indicators, http://data.worldbank.org/indicator (pristup: 04.02.2020.)

37. World Business Council for Sustainable Development (2002). The Business Case for Sustainable Development - Making a Difference towards the Earth Summit 2002 and Beyond, Corporate Environmental Strategy, 9(3), 226-235.

38. World Economic Forum (2018). Global Competitiveness Report, https://www.weforum.org/reports/the-global-competitveness-report-2018 (pristup: 04.02.2020.)

39. Yang, F.-J., Lin, C.-W. \& Chang, Y.-N. (2010). The linkage between corporate social performance and corporate financial performance. African Journal of Business Management, 4(4), 406-413.

40. Yoon, Y., Gürhan-Canli, Z. \& Schwarz, N. (2006). The Effect of Corporate Social Responsibility (CSR) Activities on Companies With Bad Reputations. Journal of Consumer Psychology, 16(4), 377-390.

41. Zakon o računovodstvu, Narodne novine 78/15, 134/15, 120/16, 116/18, 42/20, 47/20. 